\title{
聴覚障害者の視覚と聴覚による音声知覚の評価
}

\author{
福田友美子 ${ }^{1)}$ 四日市 章 ${ }^{2}$
}

要 約：読話を併用すると音声知覚能力が有利になるような比較的障害の重い聴覚障害者の 音声知覚能力を評価するための方法を作成した。その方法とは, 聴取十読話・聴取だけ・読話 だけの 3 条件での音声知覚の成績を比較できるように, 単音節・単語・文の各レベルについて, (A)音韻分布 (B)同口形音韻の分布 (C)時間的な長さ (D)意味的な難易度の分布に関して等しい頻度 から成る等価りストを録音・録画し，ビデオモニ夕に通じて提示し，音声の知覚能力を調べる ものである.

この方法を用いて, ろう学校中等部の先天性聴覚障害者 22 名の音声知覚を評価した. その結 果, 次のことがわかった。(1)評価の結果, 視覚と聴覚の併用の効果がはっきりと認められたの は 9 人, 認められなかった者は 6 人であった。 (2)併用効果有・不明・無の群の聴覚障害者の聴 力は, 有・不明・無の順に低下する傾向にあった。(3)併用効果有と無の群の間には視覚による 音声知覚の成績には差はなく, 両者の差は聴覚による音声知覚能力の差がその原因と考えられ た.

以上の結果から, 補聴器の使用が音声知覚に寄与しないような聴覚障害者には, 補聴器以外 から音声情報を取り込む方法を試みる必要性が示唆された。

索引用語 : 音声知覚, 評価, 読話, 感覚補助機器

\section{Evaluating Auditory and Visual Speech Perception Ability in the Hearing Impaired}

\author{
Yumiko Fukuda' ${ }^{1)}$, Akira Yokkaichi' ${ }^{2}$
}

\begin{abstract}
A method to evaluate speech perception ability by combined use of lip-reading and residual hearing was developed. The test materials consisted of sets of lists of Japanese syllables, words and sentences recorded on video tape. Phonemes, visemes (visual phememes), length and familiarity were evenly distributed among the lists for each set.

Using this newly developed method, an experiment to evaluate speech perception ability was conducted on 22 congenitally hearing impaired students at a junior high school for the deaf. The results as folloes. (1) Nine among the 22 subjects showed positive results through combined use of auditory and visual perception, while 6 showed no effect and the rest showed moderate effect. (2) The hearing level of the subjects belonging to the each group, tended to decrease in order of positive, moderate and no-effect groups. (3) There was no
\end{abstract}

1) 国立身体障害者リハビリテーションセンター研究所：テ359 埼玉県所沢市並木 4-1

2) 筑波大学心身障害系： 7305 茨城県つくば市天王台 1-1-1

1) Research Institute, National Rehabilitation Center for the Disabled : Namiki, 4-1 Tokorozawa-shi 359

2) University of Tsukuba : Tennodai 1-1-1, Tsukuba-shi 305

原稿受理 : 1991 年 10 月 1 日 
significant difference in the number of correct answers for visual perception between the positive and no-effect groups, indicating that the difference in effect was due to auditory speech perception ability.

These results suggest that it is indispensable to try utilizing the other perception channels for speech in case where a hearing aid serve no useful purpose for speech perception.

Key words : Speech Perception, Evaluation, Lip-reading, Sensory Aids

\section{I 、はじめに}

高度聴覚障害者が音声を知覚する場合, 視覚によっ て音声を知覚する読話情報が重要なことはよく知られ ているが，これまで，読話による音声知覚能力を評価 する方法の必要性は, 認められていながらもほとんど 提案されなかった. 1978 年に De Fillipo らによって, 振動触覚補助機器の使用効果を読話と併用した状態で 評価しようと，対面の条件で物語などの発話を肉組十 口形／ロ形だけ／肉声だけで提示して模做させ，1分 あたり何語正しく模做できたかを指標とするスピー チ・トラッキング法1)が提唱されると，スピーチ・トラ ッキング法が人工内耳患者をはじめとした障害の重い 聴覚障害者の, 読話を併用しての音声知覚の評価に広 く用いられるようになった。しかし，スピーチ・トラ ッキング法には, 次のような種々の欠点も報告されて いる.まず，スピーチ・トラッキング法は対面の状況 で行うから発話者の個人差によって結果が違ってくる 可能性がある.特に，発話速度は，それによって $30 \%$ の誤差が生じたという報告もある ${ }^{2)}$ が，発話者が対象 者の反応によって調節することになりがちで，個々の 対象者を同一の基準で評価しているとはいえない。ま た, 発話者と対象者の親密度や使用するテキスト (20 30\%の誤差が生じた例が報告されている $\left.{ }^{2)}\right)$ など も評価結果に影響を与える，スピーチ・トラッキング 法は, 個人の音声知覚能力の変化を経時的にとらえる 方法には向いているが, 多数の聴覚障害者の評価結果 を比較しなければならない目的にたいしては不適切で あると考え，発話を録音録画して，同一の評価条件で 評価できる方法を作成し，その評価法を先天性聴覚障 害者の視覚と聴覚を用いた音声知覚能力の評価に試用 した。

\section{II．視覚と聴覚による音声知覚の評価法}

\section{1. 目的}

この評価法は, 聴覚能力が音声知覚に大きく制限が あるため口形の情報を併用すると音声知覚が有利にな るような比較的障害の重い聴覚障害者の音声知覚能力
を評価できることを目的として作成した．また，視覚 と聴覚の併用効果が調べられるように, 視覚+聴覚・ 視覚だけ・聴覚だけの条件での成績を比較できるよう することも目的とした，評価の材料には，単語や文の ような意味を持つものも使用しなければならない場合 もあるので, 同じ材料を繰り返して用いることができ ない.そこで，異なった材料でも評価の結果を比較で きるような等価なリストを用意する必要がある．その ために, 聴覚障害者が, 聴覚によって/視覚によって, 音声を知覚する成績に影響を及ほすと考えられる要因 についてバランスをとれば，等価なリストが作製され ると考え, 日本語の基本語彙について, それらの項目 について記述したデータベースを作り，それを活用し て各項目のバランスを取ってリストを構築する方法を 取ることにした。

\section{2、聴覚障害者の音声知覚に影響を及ぼす要因}

聴覚障害者が音声を知覚するのに影響を及ほす要因 として, 次のようなものを考えた。

A. 音声学的要因：ある言語の聞き取り能力を反映 させられるようなリストを作製するには，その言語と 同様な頻度になるように音声学的にバランスをとる方 法が提唱され ${ }^{3)}$, アメリカ合衆国においては広く普及 している。日本語では, 国立国語研究所発行の「現代 用語の基礎調查」と「婦人雑誌の用語」(秀英出版) を

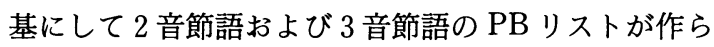
れている4). 上記のもの ${ }^{3)}$ では聴覚障害者の評価のため には難しすぎるために，アメリカ合衆国では同じ考え を基にして聴覚障害者の音声知覚能力を評価するため のリストも作られた ${ }^{5)}$.また, 音声学的なバランスをと る方法として, その言語の音素の出現頻度でバランス

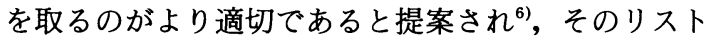
もつくられた

B．口形による要因：聴覚障害者は聴覚によって音 声を知覚する能力が制限されるために口形の情報を補 助的に使用すれば音声の了解性が向上する可能性があ り, 中等度の難聴者であっても読話を利用しているこ とが多い ${ }^{8)}$. 口形から得られるのは, 音声情報の一部に すぎず，同じ口形でも異なった音素であるものも多い 
(たとえば, $/ \mathrm{p} /$ と $/ \mathrm{b} /$ と $/ \mathrm{m} /$ など).アメリカ合衆国にお いては, 音声の音素 phoneme に対して, 口形の読話素 viseme の提案がされている と同様に，口形情報である読話素のバランスをその言 語と同様にとって,リストを作製する必要がでてくる.

C. 意味的な要因：聴覚障害者が聴覚的視覚的に捉 えるのは，正常者に比べると，曖味な刺激であると考 えられる，そのような状況では知覚の誤りの生じる可 能性は高く, 意味的に難易な内容のほうが容易なもの よりも，誤りやすくなる ${ }^{10)}$.

D. 時間的な長さ：音声を知覚する時，音声・ロ形 の刺激の系列を記憶する課程をたどると思われるの で，時間的な長さ（日本語の場合には，モーラ数）も 要因のひとつに加えた。

\section{3.評価用リストの作製}

（1）データーベースの作成

まず，データベースに登録する語彙として，国立国 語研究所編「日本語教育のための基本語彙調查」(秀英 出版，1984）のうち，「基本語二千」の 2030 語を選択 した。これは，留学生など外国人の日本語学習者が, 専門的領域の研究または職業訓練に入る基礎として, 学習するべき日本語の一般的・基本的語彙について妥 当な基準を得るという目的で選定されたものである. これらの各語彙について，表 1 に示した各項目の特性 を入力して，データーベースを作成した。

（2）評価リストの作成

評価リストは，音節・単語・文の言語学的に異なっ た 3 つのレベルのものを作成した。

A．音節リスト：日本の耳鼻咽喉科の領域で最も一 般的に使われている評価方法は，日本オーディオロジ 学会で制定した 57 式の単音節の評価用オーディオテ 一プである．従来の評価方法と互換性がもてるよう, また, 57 式りストが高出現頻度の音節で構成されてい るという 2 つの理由から，この評価材料の単音節リス トも 57 式リストと同じ構成にし,同じ発話のマスター テープから提示順序を違えて編集して，5リストを作 製した。

B，单語リスト：国立国語研究所編「日本語教育の ための基本語彙調査」(秀英出版，1984）の「基本語二 千」の単語全体と, 意味の難易の程度・文法的な分類・ 音素の分布・同口形音の分布・語獣の構成モーラ数に ついて，同様の分布になるようにしてある. 50 単語で 構成した 5 リストを作製した。

C. 文リスト：文リストには，1～8 文節の 24 文・ 100 文節で構成した。文で使用される単語は国立国語 研究所「日本語教育のための基本語彙調査」の基本語
表 1 評価リスト作製のための日本語基本語彙のデー ターベースの項目

1. 言語的情報として
A. 語彙の難易度 ${ }^{11}$
B. 語彙の意味的な分類 ${ }^{11}$
C. 語彙の文法的な分類 ${ }^{11)}$

2 . 聴賞的情報として
A. 単語を構成する音素の数 ${ }^{12)}$
B. 語彙のモーラ数

3. 視覚的情報として
A. 語彙を構成する同口形音 (viseme：読話素) の数 ${ }^{13}$
B. 語彙のモーラ数

彙二千から選択した 5 リスト。各リストは，母音・子 音の調音方法別に分類した群・文節の構成モーラ数・ 同口形音韻の分布について，釣合をとった。聴覚障害 者では，子音を聴覚的に調音方法の群として視覚的に 調音場所の群として知覚する傾向がある ${ }^{8,14,15)}$ ，そこ で，音素でバランスを取るのが難しかったので，音素 の出現頻度でなく調音方法別・調音場所別の分布でバ ランスを取った。

\section{（3）リストの等価性の検討}

日常的に補聴器を装用し，補聴器を使用し読話も音 声知覚に併用して音声知覚を行っていると思われる先 天性の聴覚障害者（平均聴力レベル $80 \mathrm{~dB} \sim 110 \mathrm{~dB}$, 19〜21 歳）9名を対象にしてリストの等価性を調べ た。これらの被験者の言語能力は, 読書力検查による と小学校 5 年から中学校 3 年の間であった.

図 1〜3の上部に，音節リスト・単語リス卜・文リ ストについての各被験者のリスト 1 〜 5 に対する最高 正答率と最低正答率の幅とその中央の值を丸で示し た. 図の下部には, リスト $1 \sim 5$ についての 9 人の各 被験者の中の最高正答率と最低正答率の幅とその中央 の值を示した．図より，各被験者の音声知覚能力には 大きな個人差があることがわかる，リスト間の正答率 の変動の幅は, 最大の変動を示した被験者で文リス ト・単語リスト・音節リストでそれぞれ $27 \%$ ・ $20 \%$ ・ $20 \%$ ，最小の被験者では $8 \% ・ 4 \% ・ 2 \% ， そ の$ 平均

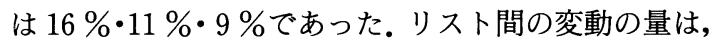
音節・単語・文の順に大きくなる傾向にあった，分散 分析を行ったところでは，単音節・単語・文のすべて で $5 \%$ の危険率でリストの平均差はなく，いずれのリ ストを用いた測定も結果を比較のために用いてよいと 考えられ，所期の目的のための評価法が得られたこと 


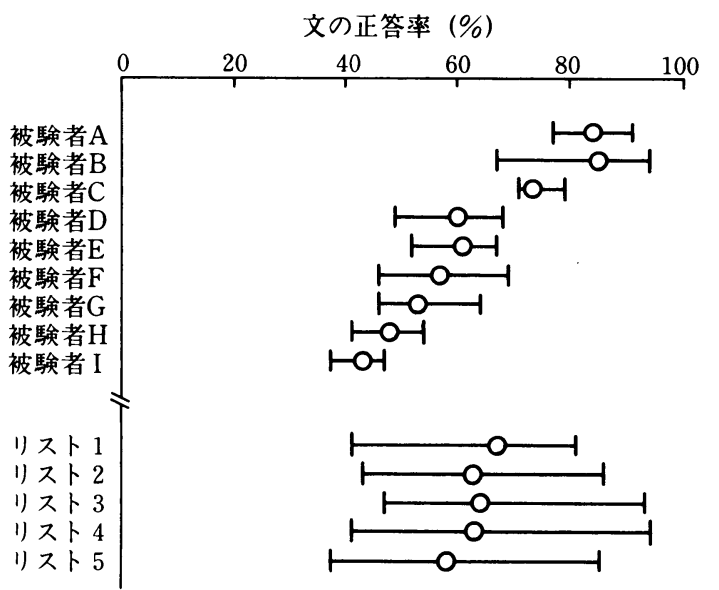

図 1 音節リストに対する正答率の変動

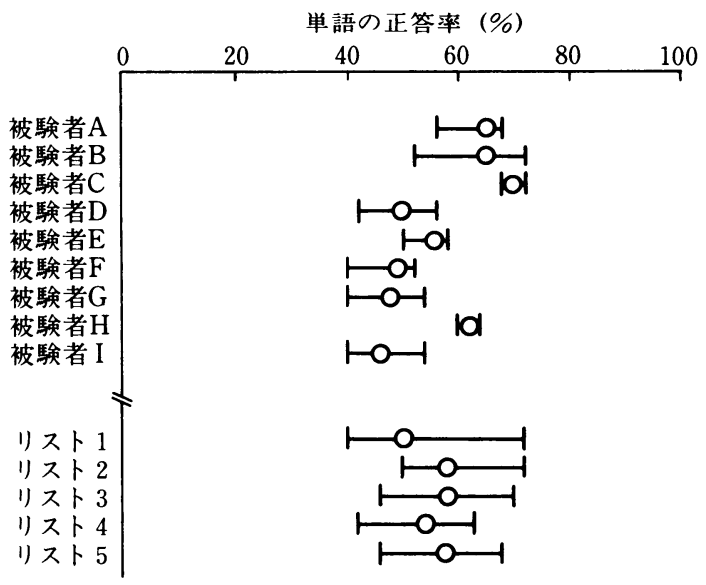

図 2 単語リストに対する正答率の変動

になる。

また, 視覚十聴覚・視覚・聴覚による音声知覚の成 績を比較するにあたっては, リスト間の変動が音節・ 単語・文の順に大きいことを考慮する必要があると考 えられる. 各被験者の音声知覚能力には大きな個人差 が存在するので各被験者の正答率の平均を，9人の全 体の平均値に正規化しリスト間の変動の量を求め, 図 4 に示した(丸が平均值を幅が標準偏差を示した)。本 研究の先天性聴覚障害者の音声知覚の評価では,この 量を参考にして文・単語・音節に対する視覚十聴覚・ 視覚・聴覚による音声知覚の成績の比較を行った。

\section{II. 先天性聴覚障害者の視覚と聴覚による 音声知覚の評価}

\section{1. 方法}

作製した評価リストを用いて先天性聴覚障害者の視

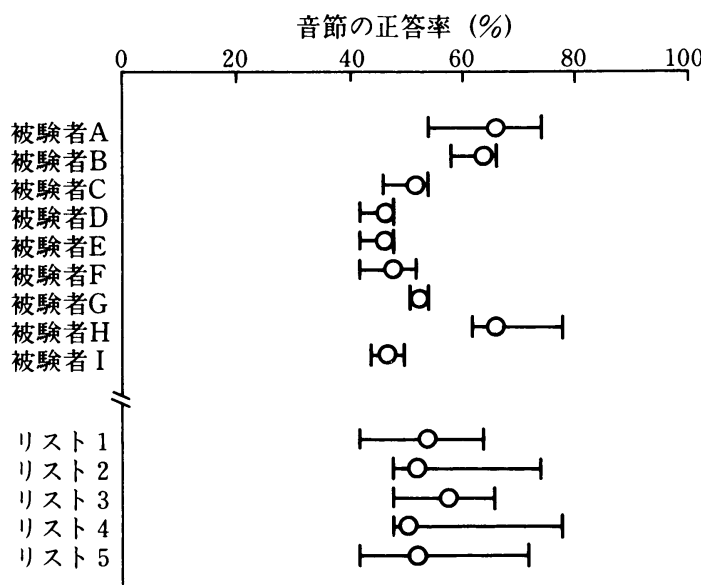

図 3 文リストに対する正答率の変動

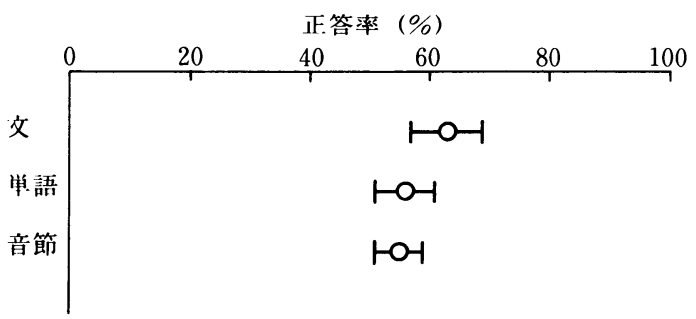

図 4 文・単語・音節のリスト間の変動量

覚と聴覚による音声知覚の評価を行った.まず, 音節・ 単語・文の各リストの発話を, Uマチック・ビデオコ ーダ (SONY VO-5800), ビデオカメラ (SONY DXC -1310), エレクトレット・コンデンサ・マイクロフォ ン (SONY ECM-23 F) を用いて，防音室内で録音・ 録画を行い，まず，マスターテープを作製した。この マスターテープから, Uマチック・エディチングレコ ダー (SONY VO-5850) とエディティングコントロー ラ（SONY RM-440）を用いて編集して, 評価実験で 用いるビデオテープを作製した，画面に検査語の順番 に数字をスーパインポーズして, 検査の実施を便利に した.

発話者は，聴覚障害者との対話に慣れている標準語 を話す成人女性 1 名である、録音にあたっては，騒音 計で監視して, 一定の音量で話すように心掛けた。録 画は, 話者の正面から撮影し, 話者の頸部から頭全体 が画面に入るようにした，また， 2 個の照明を頭の高 さの左右の $45^{\circ}$ 角度から当て, 読話の手掛かりとな る舌の動きや歯などがよくみえるように留意した。

対象は, ろう学校中等部に在籍している 22 名の生徒 で, ろう学校の静かな部屋でビデオモニターを通じて 音声・画像を提示し, 解答を解答用紙に書き取らせる 
方法で評価を実施した。音声の提示音圧は約 $75 \mathrm{~dB}$ SPLで，ほとんどの対象者がこの位の大きさがよいと いう大きさであった。

\section{2. 結果}

（1）視覚と聴覚の併用効果

先天性の聴覚障害者 22 人の結果から, (視覚 + 聴覚 の条件での正答率) - (視覚だけでの正答率) を求め, その值が文・単語・音節のすべてでリスト間の変動の 量 (本研究では 9 人の測定より求めた 2 標準偏差を用 いた)より大きいものを，視覚と聴覚の併用効果が有 ${ }^{1)}$ と, 逆に, 文・単語・音節のすべてで差が変動の值よ りも小さいものを併用効果は無と, いずれかの值が大 きいものは併用効果不明と判定した。併用効果有が 9 人，無が 6 人，不明が 7 人であった。それぞれの群の 対象者の補聴器装用耳（両耳装用の場合は良聴耳）の 聴力を，オージオグラム上に重ね合わせたものを図 5 に示した. 併用効果有 ・不明 - 無の群の順に聴力が低 下する傾向にあったが，はっきりとした境界はなかっ
た。

また， 3 群の文・単語・音節での 3 条件での正答率 の平均とその標準偏差を図 6 に示したが, 文・単語・ 音節のすべてで, 視覚十聴覚と聴覚だけの 2 条件では, 併用効果の有の群，不明の群，無の群の順に正答率が 低くなっていた。一方，視覚だけの条件では 3 群の間 に差はなく，視覚＋聴覚での成績の差は，聴覚による 知覚能力の差が原因と考えられた。

（2）母音・子音の知覚

併用効果有の群の 9 人と無の群の 6 人の音節の異聴 の結果から得られた， 3 条件での母音の異聴表を示し た(図 7 )。この図でも，併用効果有の群と無の群の違 いは,聴覚による知覚能力によることは明らかである. 日本語では母音は 5 個しかないため, 視覚だけと条件 でもほぼ 5 母音を識別できるが併用効果有の群では, 聴覚を併用することで正答率が向上している. 一方無 の群では, 知覚能力の劣る聴覚を併用したことによっ て，正答率が視覚だけの場合よりもやや劣っているよ

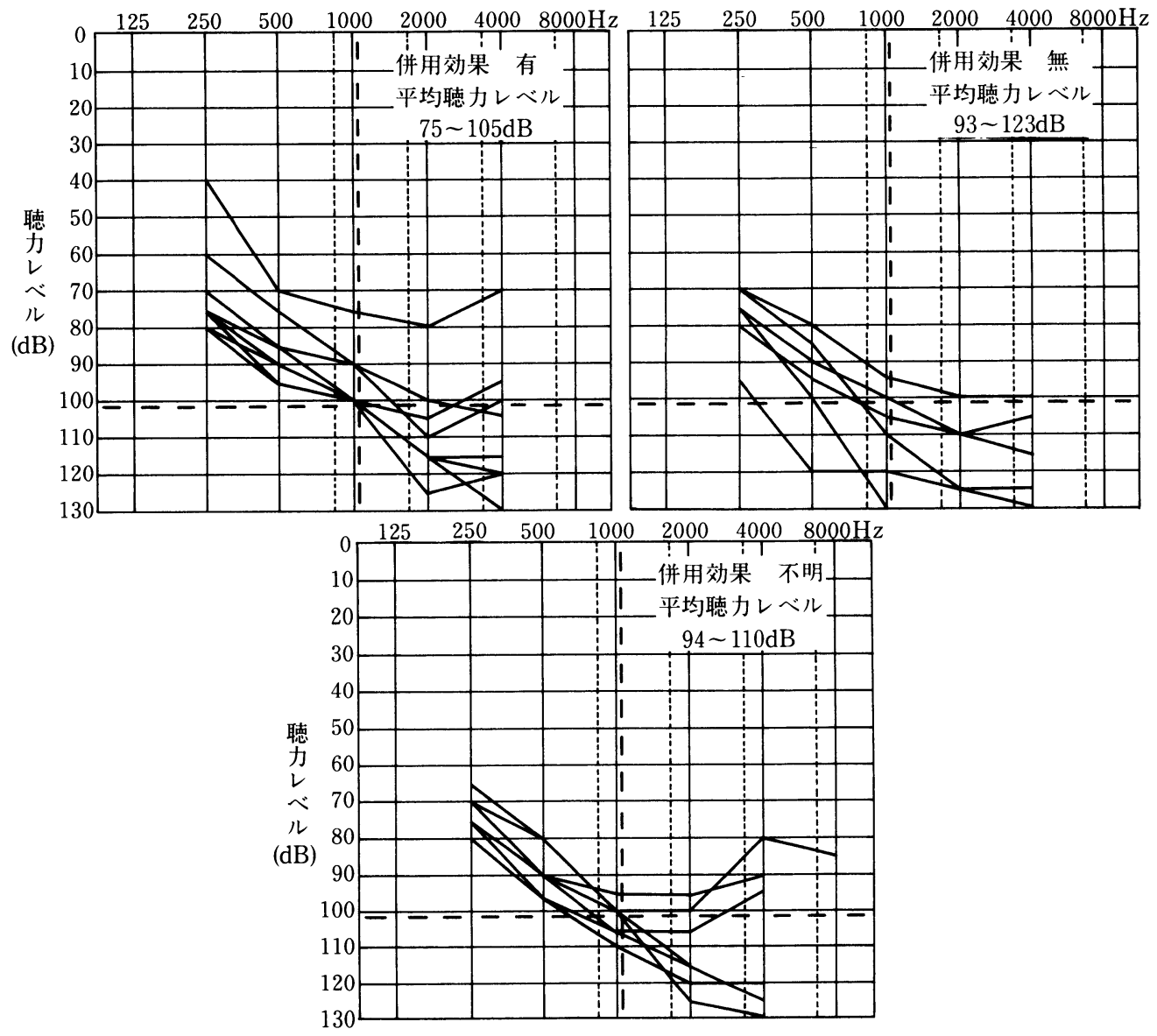

図 5 併用効果有・不明・無の群の聴力図 


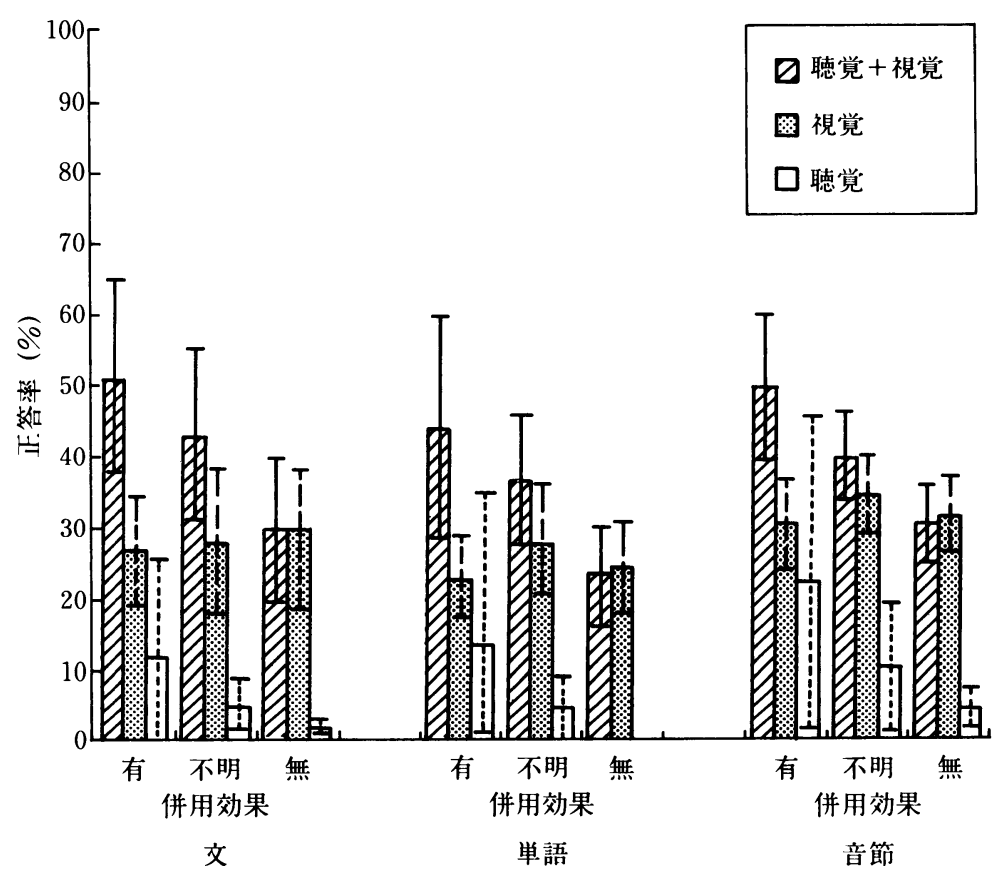

図 6 併用効果有・不明 - 無の群の, 視覚十聴覚 - 視覚 - 聴覚の各条件 での, 音節・単語・文に対する正答率

併用効果有の群

(5\%以下省略)

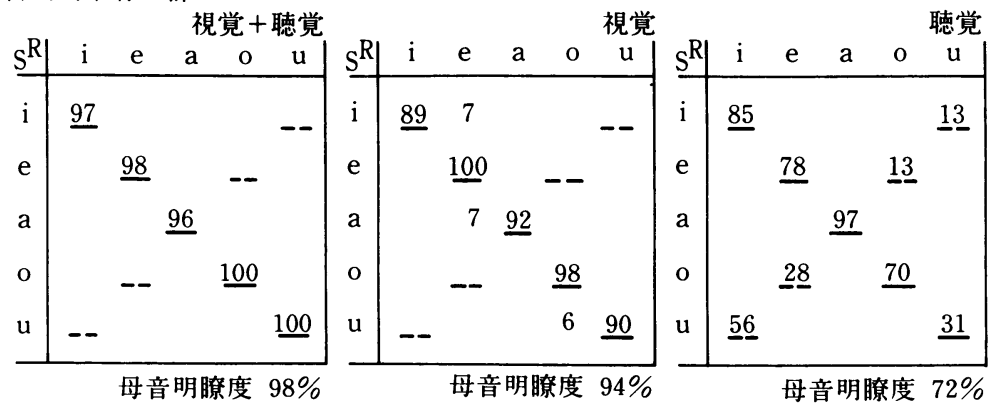
併用効果無の群

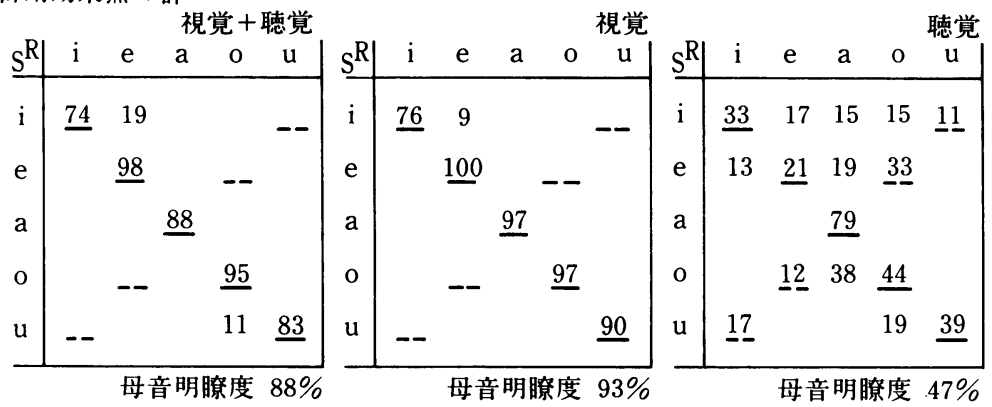

図 7 併用効果有・無の群の, 視覚 + 聴覚・視覚・聴覚の各条件で, 母 音の異聴表 
うすがみられる。

子音の知覚について, 視覚からは調音場所について 聴覚は調音方法についての情報が知覚されやすく，視 覚と聴覚を併用するとそれらが相補的に働いて知覚の 成績が向上することが, 補聴器を装用している先天性 の聴覚障害者でも ${ }^{8,10)}$ 人工内耳患者でも ${ }^{14,15}$ 報告され ている. 本研究の対象者の子音明瞭度は, 併用効果有 の群では, 聴覚十視覚・視覚・聴覚の各条件で, $52 \%$ ・ $34 \% \cdot 30 \%$ で，一方無の群では， $34 \% \cdot 34 \% ・ 12 \%$ であった. 両者の聴覚による知覚を比較するために, 併用効果有 ・無の群の音節の異聴の結果から得られた 3 条件での子音の異聴表より, 調音方法別に正答率を 調べた(図 8 )。なお，波線はそれぞれの正答のチャン スレベルを示してある. 本研究では両者に大きな差が あったのは, 鼻音・半母音で, ついで無声破裂・摩擦 音であった。

\section{3. 考察}

併用効果のある群の結果を, 後天性の聴覚障害者で ある人工内耳の患者の結果と対比してみた(図 9 )。人 工内耳患者 $\mathrm{A}$ は電話の使用も可能な音声知覚能力の良 好な例であるが，患者 $\mathrm{B}$ はあり良好でない患者であ る. 患者 $\mathrm{A} て ゙ は$ 聴覚だけの条件の正答率が音節く単 語＜文となっているのに対し，患者Bでは音節＝文＞ 単語で，Aの方がかなり正答率が高い．視覚だけの条 件では，両者とも音節では良好であるが文・単語では 低い. 患者Aの結果は, 手術後数年という短期間で, 過去に蓄積された音声言語の辞書と対応させて急速に 人工内耳聴覚のための新しい辞書が構築されているこ とを示すとともに，視覚系のための辞書の作製は困難

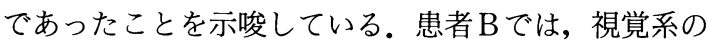
ための辞書の作製は困難であったことはAの場合と同 様であるが,さらに聴覚による知覚も先天性聴覚障害 者の併用効果有の群に比べても芳しくない. しかし，

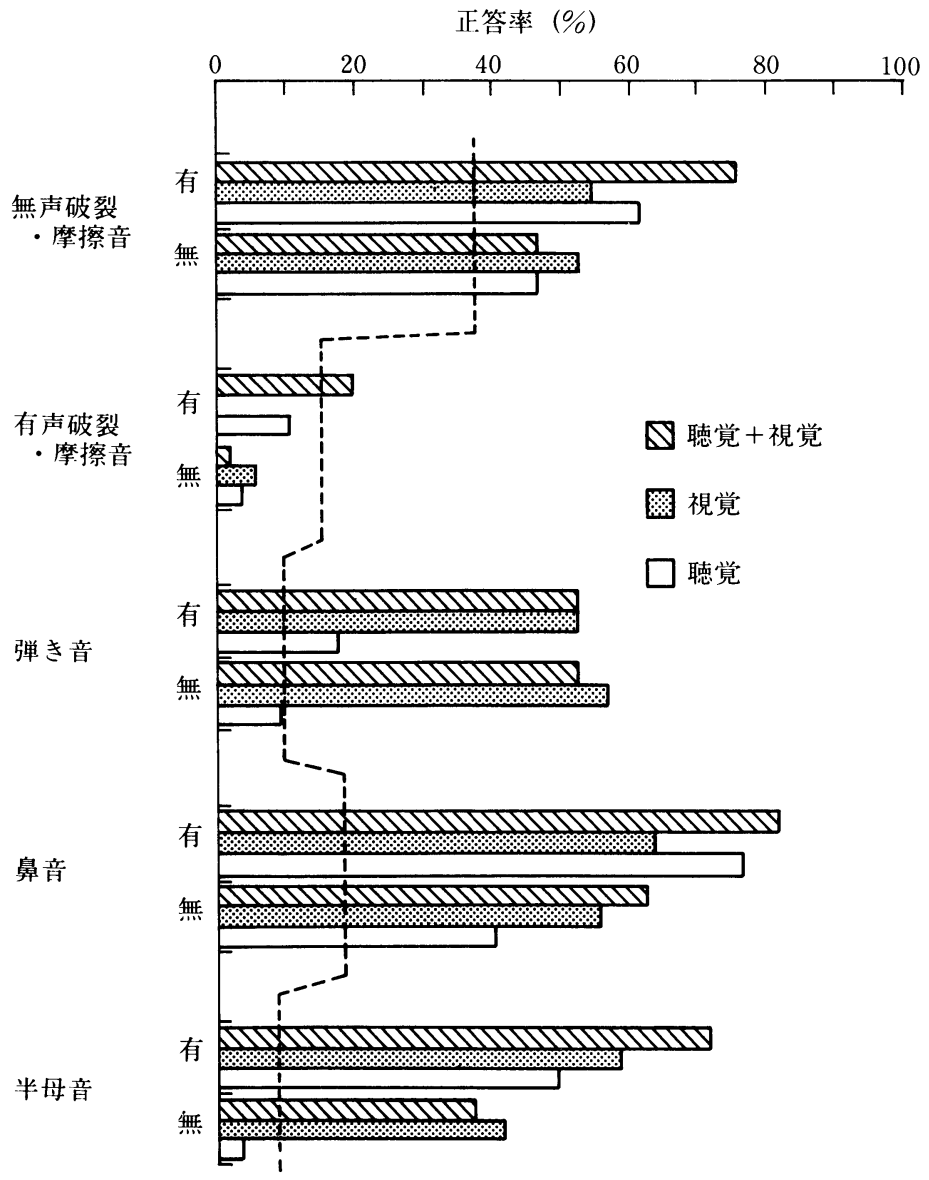

図 8 併用効果有・無の群の, 視覚+聴覚・視覚・聴覚の各条件での, 子音の調音方法別の正答率 


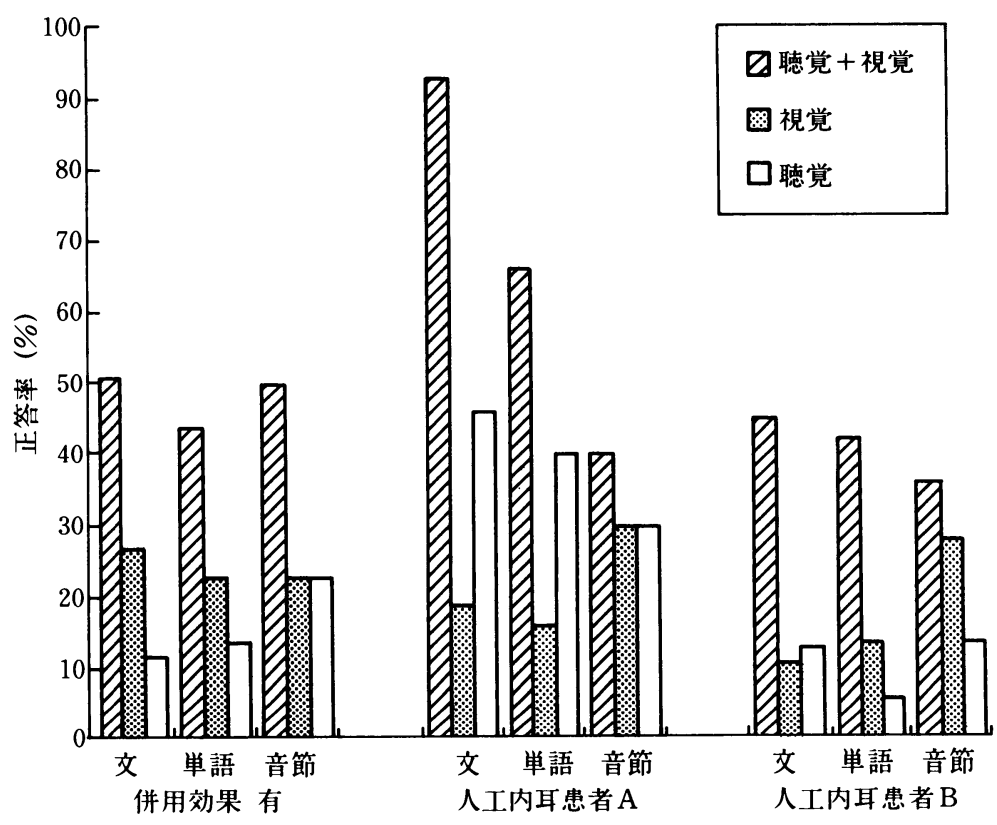

図 9 併用効果有の群と人工内耳埋め込み患者の, 視覚 + 聴覚・視覚・ 聴覚の各条件での，音節・単語・文に対する正答率

文の知覚では視覚によるものよりも聴覚による方が高 くまた併用の効果が大きいのは, 過去に完全な日本語 能力と音声知覚のための体系を獲得していたことが有 利に働いていると思われる.

一方先天性の聴覚障害者では, 視覚の条件では音 節・単語・文の順に正答率が上昇し, 聴覚の条件では 音節・単語・文の順に逆に下降している。このことよ り, 本研究で対象にした先天性の聴覚障害では, 視覚 によって音声言語を知覚するための辞書の作製の方が 聴覚系のものよりも容易であったことが推察される.

図 10 に視覚と聴覚の併用効果がみられない群の成 績を示した.これらの対象者も補聴器の装用の効果が 全くないということでなく, 音の存在がわかるなどの 恩恵を受けており, 日常的に補聴器を使用しているが, 音声を知覚するレベルでははっきりとした効果がある とは認められない. 補聴器の装用と早期教育が提言さ れてかなりの年月が経過し，現在，わが国は国際的に も早期教育がもっとも充実している国の 1 つとなり, 統合教育も広く実施されている. しかし, 補聴器の効 果がごく限られている聴覚障害者に対しての教育方法 については, きわめて未熟な状態にある. 現在, 諸外 国では, 人工内耳や人工内耳の適応が望ましくない場 合には振動触覚補助機器などを与えて音声知覚能力を 向上される試みが多数報告されている，われわれも， そのような補聴機器を導入する必要があるように思わ

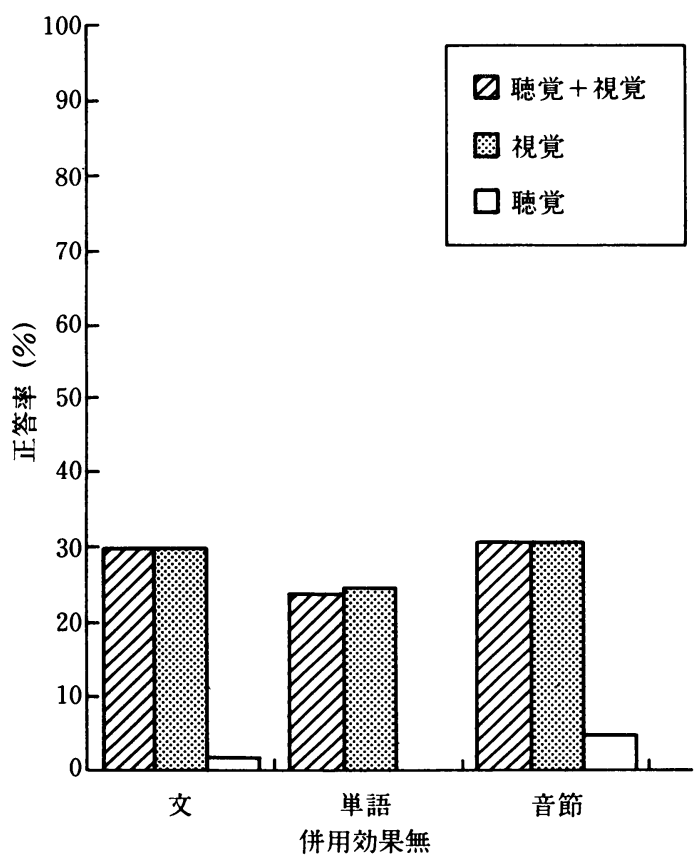

図 10 併用効果無の群の, 視覚十聴賞・視覚 - 聴覚 の各条件での, 音節・単語・文に対する正答 率 
れた。

この研究の前半の評価法の作成は福田が行い, ビデオテープの 作成については早稲田大学人間科学部の比企静雄教授に援助い ただいた，後半の試用実験は，福田と四日市と協同して行い，実 施にあたっては東京学芸大学大学院生加藤ふみ氏にご協力いた だいた。また，評価の対象となった人工内耳患者は東京医科大学 において手術・リハビリテーションを行った患者である。

ここに，ご協力をいただいた皆様に深く感謝する.

\section{文献}

1) De Fillippo, C. L. and Scott, B. L. : A method for training and evaluating the reception of ongoing speech, J. Acoust. Soc. Am., 63 : 1186 〜192, 1978.

2) Levitt, H. : Evaluation of a cochlear prosthesis using connected doscourse tracing, J. Rehabilitation Research, $23:$ 147 154, 1986.

3) Egan, J. P. : Articulation testing method, Laryngoscope, 58 : 955 991, 1948.

4）三浦種敏・山口善利 : 第 4 部音声情報の知覚, 聴 覚と音声，電子通信学会発行，343～345，1968。

5) Hirsh, I. J., Davis, H., Silberman, S. R., Reynolds, E., Eldert,E., and Bemson., R. W. : Development of materials for speech audiometry, J. Speech Hear. Dis., 17 : 321 337, 1952.

6) Lehiste, I., and Peterson, G. E. : Linguistic consideration in the study of speech intelligibility, J. Acoust. Soc. Am., 31 : 280 286, 1959.

7) Tillman, T. W., and Olsen,W. O. : Speech audiometry, in Jerger, J. ed., Modern Develoments in Audiology, (Second Edition), New York, Academic Press, 1973.

8）福田友美子, 坂本 幸, 黒木総一郎：読話に対す る残聴の併用効果, 日本音響学会誌, 32 : 271 276, 1976.

9) Fisher, C. G. : Confusion among visually perceived consonats, J. Speech Hear. Res., 3 : 212 $\sim 222,1960$.

10）福田友美子, 比企静雄 : 読話と残存聴能の活用と の相互関係, 日本音響学会誌, $33 ： 198 \sim 207,1977$.

11）国立国語研究所：日本語教育のための基本語彙調 査, 秀英出版, 1984 .

12）服部四郎：言語学の方法, 岩波書店, 1960.

13) Fukuda, Y. and Hiki, H : Characteristics of the mouth shape in the production of JapaneseStroboscopic observation, Journal of the Acoustical Society of Japan (E), 2 :75 91, 1982.

14）舩坂宗太郎，城間将江，湯川久美子，飯塚尚久, 挑 敏明, 河野 淳, 高橋 整, 熊川孝三：22 チ ヤンネル人工内耳患者の子音・半母音情報伝達量 に関する研究, AUDIOLOGY JAPAN, 32： 146 152, 1989 .

15）福田友美子, 城間将江，舩坂宗太郎：人工内耳埋 め込み患者の音声の知覚一聴覚と視覚の併用につ いて，音声言語医学，30：334～339，1989.

\section{別刷請求先 : $\mathbf{T} 359$ 埼玉県所沢市並木 4-1}

国立身体障害者リハビリテーションセンター 研究所

福田友美子 